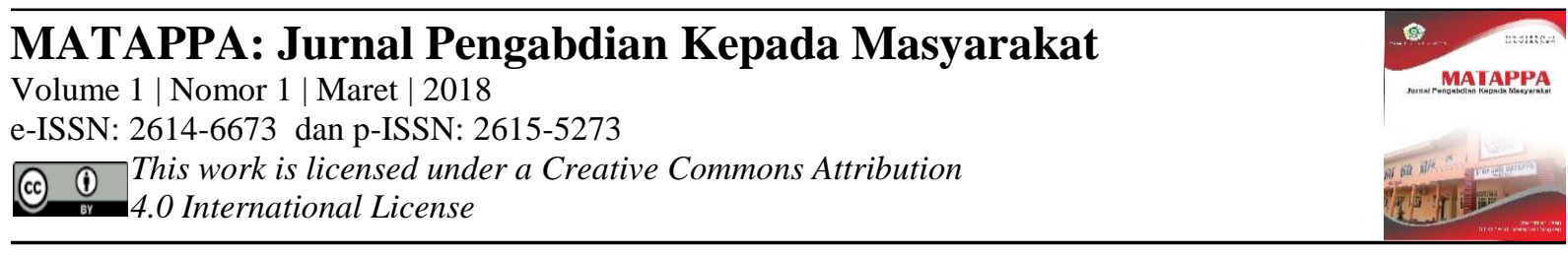

\title{
Pelatihan Konselor Sebaya Sebagai Strategi Pemecahan Masalah Siswa
}

\section{Salmiati ${ }^{1}$ Hasbahuddin ${ }^{2}$ Muhammad Ilham Bakhtiar ${ }^{3}$}

\begin{tabular}{l}
\hline Keywords: \\
Pelatihan; \\
Konselor sebaya; \\
Pemecahan Masalah. \\
\\
Corespondensi Author \\
')STKIP Andi Matappa \\
Email: salmi_unm86@yahoo.co.id \\
${ }^{2)}$ STKIP Andi Matappa \\
Email:hasba_konseling@yahoo.com \\
3)STKIP Andi Matappa \\
Email:ilhambakhtiar86@ gmail.com
\end{tabular}

History Artikel

Received: 24-02-2018

Reviewed: 27-02-2018

Revised: $12-03-2018$

Accepted: 20-03-2018

Published: 30-03-2018

\begin{abstract}
ABSTRAK
Tujuan dari kegiatan adalah membentuk kelompok konselor sebaya di sekolah untuk membantu mensosialisasikan peran dan fungsi bimbingan konseling, meningkatkan kompetensi diri (pribadi yang positif) agar mampu menjadi konselor, membantu memecahkan permasalahan teman sebaya melalui kegiatan konseling. Pelaksanakan kegiatan pelatihan konselor sebaya dilaksanakan dengan menggunakan metode pelatihan dan pendampingan, dimana pelaksanaan kedua metode tesebut dilakukan dengan cara: Ceramah/Pemberian Informasi, Role Play, Focused Group Discussion (FGD), Simulasi dan Latihan, Refleksi. Hasil kegiatan pelatihan antara lain: meningkatkan performansi bimbingan konseling melalui kegiatan konseling sebaya, memberikan penghargaan dan perhatian terhadap siswa dengan melakukan kegiatan positif dalam bimbingan konseling di sekolah, mengantisipasi munculnya perilaku negatif remaja (kenakalan remaja), memberikan nilai tambah dalam bidang pengetahuan dan keterampilan untuk siswa sehingga dapat membantu guru bimbingan dan konseling.
\end{abstract}

\section{PENDAHULUAN}

Masa remaja adalah masa yang sangat rentang dengan berbagai permasalahan baik masalah pribadi, belajar, sosial dan karir. Permasalahan remaja tidak hanya menjadi tanggungjawab keluarga tetapi juga tanggungjawab sekolah sebagai lembaga pendidikan formal. Salah satu unit penanganan masalah siswa di sekolah adalah unit pelayanan bimbingan konseling yang memiliki peran dan fungsi yang strategis dalam pola pembentukan karakter dan perilaku sukses saat belajar di sekolah. Namun demikian masih sedikit siswa (remaja) memanfaatkan jasa bimbingan dan konseling di sekolah untuk membantu menyelesaikan masalahnya maupun mengembangkan potensi dirinya. Bimbingan dan konseling masih sering dianggap oleh siswa (remaja) sebagai lembaga pengadil bagi perilaku negatif yang dilakukan sehingga siswa cenderung menghindari hal-hal yang berkaitan dengan bimbingan dan konseling. Penelitian Sari (2010) menyimpulkan bahwa mahasiswa mempunyai persepsi yang negatif terhadap guru BK.

Sementara hasil penelitian yang lain menunjukkan bahwa mahasiswa yang mempunyai persepsi positif menunjukkan minat yang kuat untuk menggunakan layanan bimbingan dan konseling sebanyak $10 \%$ (Wahyudin, 2013). Penelitian yang hampir sama juga dilakukan oleh Mardiana dkk (2012) menunjukkan bahwa persepsi dan sikap mahasiswa terhadap layanan bimbingan dan konseling juga kurang menggembirakan. Hal ini menunjukkan bahwa secara empirik layanan bimbingan dan konseling belum berjalan dengan baik akibat adanya persepsi dan sikap peserta 
didik yang tidak memberikan apresiasi yang positif terhadap peran dan fungsi bimbingan dan konseling di sekolah.

Fenomena tersebut di atas, secara umum terjadi di sekolah. siswa pada umunya lebih nyaman bercerita kepada teman sebaya dibandingkan datang keruangan bimbingan dan konseling untuk mengkonsultasikan permasalahan yang meraka hadapi. Hal ini menunjukkan bahwa ketika remaja dihadapkan pada suatu permasalahan dalam proses pencapaian tugas perkembangannya, remaja tersebut membutuhkan sahabat yang mampu menemani tugas perkembangannya dengan baik dan dapat menyelesaikan masalah yang dialaminya secara bersama-sama melalui teman sebaya. Oleh karena itu dibutuhkan sebuah strategi pengelolaan bimbingan konseling yang baru untuk membantu siswa dalam memecahkan permasalahan yang dihadapinya. Salah satu strategi yang dapat digunakan adalah dengan membentuk kelompok konselor sebaya. Hal ini dapat dipahami karena periode remaja merupakan periode yang sangat dekat dengan peer group, membutuhkan pengakuan dari kelompok atau teman sebaya dan membutuhkan identitas baru yang bisa meningkatkan harga dirinya (Hurlock, 2002).

\section{METODE}

Kegiatan pelatihan konselor sebaya dilaksanakan di SMA Negeri 6 Bontoa Kabupaten Maros. Pelaksanaan kegiatan bertempat di Aula SMA Negeri 6 Bontoa, pada hari Sabtu, 27 Januari 2018.

Kelompok sarasan dalam kegiatan pelatihan konselor sebaya adalah siswa SMN Negeri 6 Bontoa sebanyak 10 orang siswa yang diwakili oleh 2 orang siswa dari setiap kelas yang ada di SMA Negeri 6 Bontoa. Pemilihan siswa yang menjadi perwakilan setiap kelas berdasarkan pada hasil analisi data sosiometri yang disebar terlebih dahulu sebelum kegiatan pelatihan konselor sebaya berlangsung. Selain hasil analisis data sosiometri, salah satu yang menjadi pertimbangan siswa yang menjadi sasaran dalam kegiatan pelatihan konselor sebaya adalah siswa yang memiliki indeks prestasi yang tinggi dibandingkan dengan teman-teman yang lainnya yang ada di dalam kelas dan diharapkan adanya keterwakilan siswa yang berjenis kelamin laki-laki dan siswa yang berjenis kelamin perempuan. Adapun yang menjadi instruktur dalam kegiatan ini adalah dosen-dosen Prodi Bimbingan dan Konseling
STKIP Andi Matappa seperti Salmiati, S.Pd.,M.Pd, Hasbahuddin, S.Pd.,M.Pd, dan Muh. Ilham Bakhtiar, S.Pd.,M.Pd.

Untuk memecahkan masalah yang telah diidentifikasi dan dirumuskan di atas, maka pelaksanakan kegiatan pelatihan konselor sebaya dilaksanakan dengan menggunakan metode pelatihan dan pendampingan, dimana pelaksanaan kedua metode tesebut dilakukan dengan cara: a) Ceramah/Pemberian Informasi; Kegiatan ini dimulai dengam pemberian informasi kepada peserta berkaitan dengan materi kegiatan dengan menggunakan metode cemarah. Kegiatan ini dilakukan dengan harapan siswa memiliki pemahaman yang baik terkait dengan konselor sebaya agar terjadi kesepahaman antara pemateri dengan peserta. Hal ini akan memudahkan nantinya dalam pelaksanaan latihan/simulasi. b) Role Play; Suatu bentuk permainan yang dirancang sedemikian rupa yang disusun dalam suatu skenario untuk memberi kesempatan kepada peserta melakukan suatu peran tertentu sehingga memperoleh pengalaman yang tidak simbolik semata. Didalam role play, peserta dituntut mampu menghayati suatu peran tertentu, mencoba dan merasakan menjadi seseorang tertentu dalam suatu proses, sehingga dapat lebih memahami prosesnya dan memiliki gambaran aplikasinya. Dalam kegiatan role play peserta ditempatkan pada situasi menjadi konselor dan konseli untuk mendapatkan pengalaman baru dan nyata tentang proses konseling sebaya. c) Focused Group Discussion (FGD); Suatu teknik diskusi kelompok yang digunakan untuk mendapatkan gambaran dari berbagai pendapat atau opini terhadap permasalahan yang dihadapi. Para peserta dibagi dalam 3 kelompok untuk diminta mengemukakan pendapat-pendapatnya pada suatu masalah tertentu secara terarah, tanpa harus memecahkan masalah tersebut. Dalam waktu antara 30 menit peserta diminta mendiskusikan masalah yang sudah dirancang oleh pemateri (trainer), sehingga peserta mempunyai pemahaman baru tentang berbagai masalah dari berbagai sudut pandang yang berbeda dari setiap peserta. d) Simulasi dan Latihan; Hampir sama dengan role play, tetapi peserta memerankan dirinya sendiri. Didalam simulasi, proses pelaksanaannya adalah memerankan suatu situasi nyata yang akan dihadapi peserta dimasa yang akan datang. Seorang peserta diminta untuk melakukan proses konseling sebaya, dimana salah seorang 
peserta berperan sebagai seorang konselor dan satu peserta lainnya berperan sebagai konseli yang memiliki suatu permasalahan, sedangankan peserta lain berpera sebagai penonton. Proses simulasi itu berlangaung secara bergiliran, sehingga semua peserta akan terlibat dalam proses simulasi. e) Refleksi; Kegiatan ini merupakan bagian dari evaluasi kegiatan yang bertujuan untuk mengetahui tingkat pemahaman peserta terkait dengan materi kegiatan konselor sebaya. Dalam kegiatan ini, pemateri melontarkan pertanyaan kepada peserta terkait dengan rangkaian pelaksanaan kegiatan berkaitan dengan kesan dan pesan terhadap pelaksanaan kegiatan konselor sebaya.

Langkah-langkah kegiatan konselor sebaya melalui beberapa tahapan yaitu : a) Persiapan; Tim pengabdian penjelasan kepada pihak sekolah mengenai rencana program atau kegiatan pembentukan kelompok konselor sebaya. b) Sosialisasi; Tim pengabdian masyarakat menjelaskan tentang berbagai kegiatan yang akan diikuti dan juga berkaitan dengan mekanisme pelaksanaan kegiatan, mulai dari proses pendaftaran, penentuan peserta yang akan dilibatkan dalam pelaksanaan kegiatan konselor sebaya dan membuat kesepakatan dengan masing-masing peserta untuk terlibat secara aktif serta bertanggung jawab dalam mengembangkan dan merealisasikan pelaksanaan konselor sebaya yang akan terbentuk atau bisa menjadi suatu komunitas (agen) perubahan di sekolah. c) Pelatihan dasar; Siswa yang telah terdaftar sebagai calon konselor sebaya akan di assessment dulu tentang motivasi dan karakteristik kepribadiannya serta kemampuan dasarnya sebagai calon konselor, siswa akan diundang mengikuti pelatihan dasar konseling sesuai dengan agenda kegiatan yang telah disepakati, kegiatan pelatihan ini tidak dilakukan dalam satu kali pelatihan tetapi bertahap dengan tujuan terbentuknya kemampuan konseling secara menyeluruh sesuai dengan kebutuhan, semua peserta akan mendapatkan sertifikat mengikuti pelatihan bimbingan dan konseling dan setelah selesai pelatihan para peserta diminta belajar aplikasi di sekolah. d) Pelatihan lanjutan; Tim pengabdian memberikan pelatihan lanjutan dengan fokus pada pembentukan keterampilan dan kemampuan seorang konselor, materi pelatihan akan disesuaikan dengan para siswa di sekolah sesuai dengan hasil evaluasi pasca pelatihan dan praktek di lapangan. e) Pendampingan; Tim pengabdian mengadakan pendampingan kepada kelompok konselor sebaya, kelompok konselor akan diberi kesempatan melakukan kegiatan konseling sebaya di sekolah, f) Evaluasi; Tim pengabdian masyarakat bersama-sama mengadakan evaluasi terhadap kegiatan pelatihan dan pendampingan kegiatan, evaluasi juga dilakukan secara bersama-sama dengan kelompok konselor sebaya untuk melihat kemajuan dan penerapan konseling sebaya di sekolah dan perumusan pengembangan kegiatan dan perluasan kelompok di masa depan.

\section{HASIL DAN PEMBAHASAN}

Kegiatan pelatihan konselor sebaya telah dilaksanakan dengan baik sesuai rencana yang telah disiapkan. Pelaksanaan Kegiatan dimulai dengan melalui tahapan sebagai berikut:

Persiapan Kegiatan ini memerlukan waktu yang lebih lama dalam persiapan pelaksanaannya untuk menjamin tingkat kesuksesan dalam seluruh program kegiatan tersebut. Adapun persiapan yang dilakukan meliputi : a) Menentukan lokasi (sekolah yang menjadi mitra pengabdian masyarakat) dan menentukan peserta yang menjadi sasaran pelaksanaan kegiatan konselor sebaya. b) Melakukan sosialisasi terhadap mitra kegiatan untuk memastikan keberlangsungan kegiatan ini dengan mengungkapkan time schedule dan halhal yang menjadi konsekuensi kegiatan tersebut, c) Melakukan koordinasi dan TOT (training for trainer) tentang pelatihan konseling sebaya kepada tim mahasiswa yang akan membantu program pengabdian ini secara berkelanjutan. Tim mempersiapkan 5 mahasiswa untuk menjadi trainer dan pendamping kegiatan konseling sebaya, d) Mempersiapkan materi pelatihan dan pembuatan modul konseling sebaya yang akan diberikan kepada seluruh peserta dan mitra kegiatan.

Pelaksanaan Dalam tahap pelaksanaan kegiatan pengabdian masyarakat ini sesuai dengan rencana pelaksanaan dan kesepakatan dengan mitra kegiatan. Tahapan kegiatan tersebut antara lain: a) Pembuatan modul konseling sebaya; Kegiatan ini bertujuan untuk memberikan bekal kepada peserta agar dapat melakukan kegiatan konseling sebaya dengan lebih praktis. Modul ini berisikan tentang petunjuk praktis dalam melakukan konseling sebaya disertai dengan gambar praktek konseling dan lampiran contoh proses konseling. Disamping itu modul juga dilengkapi dengan contoh kasus masalah remaja beserta petunjuk cara menyelesaikannya melalui konseling 
sebaya. Modul ini diberikan kepada seluruh peserta dan pengurus panti asuhan sebagai mitra kegiatan pengabdian ini. Diharapkan modul ini dapat dijadikan referensi bagi pelaksanaan konseling sebaya untuk memudahkan pengembangan kelompok konseling sebaya di Kota Malang. b) Pelatihan dasar; Kegiatan berikutnya adalah melakukan pelatihan dasar konseling sebaya untuk mitra kegiatan. Tujuan dari kegiatan ini adalah: Memperkenalkan program konseling sebaya sebagai alternatif pemecahan masalah (problem solving) bagi para remaja, Memberikan pengetahuan dan pemahaman tentang proses konseling sebaya, Membentuk karakteristik dasar seorang konselor sebaya, Meningkatkan kepekaan terhadap lingkungan sekitar, Membantu pengurus panti asuhan dalam mengelola berbagai permasalahan yang ada di tempat tersebut melalui program konseling sebaya. c) Pelatihan lanjutan, Sesuai dengan tujuan dilakukannya kegiatan pengabdian ini dan hasil evaluasi dari pelatihan dasar konseling sebaya, maka dibutuhkan adanya pelatihan lanjutan. Kegiatan ini bertujuan untuk; Meningkatkan kompetensi dan keterampilan peserta dalam kegiatan konseling sebaya, Membentuk karakter remaja (konselor sebaya) yang sesuai dengan kebutuhan program konseling, Menyebarluaskan teknik konseling sebaya sebagai salah satu alternatif pemecahan masalah bagi remaja. Pelatihan lanjutan dibutuhkan dalam rangka melakukan identifikasi permasalahan yang dirasakan dan dijumpai dalam aplikasi kegiatan konseling sebaya. Disamping itu pelatihan ini juga diharapkan oleh mitra kegiatan untuk meningkatkan penguasaan materi dan aplikasi konseling sebaya agar dapat diterapkan dengan baik sesuai kaidah di tempat masing-masing, sehingga dalam kegiatan ini banyak dilakukan role play dan simulasi kegiatan konseling. d) Pendampingan; Program pendampingan merupakan kegiatan yang disusun sebagai sebuah paket kegiatan untuk memastikan bahwa peserta melakukan kegiatan konseling dan memiliki kemampuan dasar yang dibutuhkan saat melakukan konseling sebaya. Disamping itu kegiatan ini juga untuk menjembatani informasi terbaru berkaitan dengan permasalahan yang dihadapi oleh temanteman sebayanya dan permasalahan individual saat melakukan kegiatan konseling, sehingga tim pengabdian masyarakat dapat menyusun langkahlangkah baru dan membantu penyelesaian masalah yang dihadapi oleh peserta dan mitra. Program pendampingan dimaksudkan untuk memberikan penguatan secara psikososial agar konselor sebaya dapat dengan mandiri dan percaya diri melakukan kegiatan konseling. Selain itu kegiatan pendampingan juga digunakan untuk melakukan sharing terhadap permasalahan yang dihadapi konseli dan permasalahan individu dalam melakukan kegiatan konseling. Program pendampingan dilakukan selama 3 kali sesuai dengan kesepakatan mitra untuk memberikan pendampingan terhadap kegiatan konseling di lokasi masing- masing. Kegiatan ini juga dimaksudkan untuk menjalin komunikasi yang lebih baik antara konselor, tim pengabdian (mentor) dan pihak kampus, agar kerjasama yang dilakukan ini dapat berkesinambungan untuk kepentingan masyarakat yang lebih luas. Disamping itu kegiatan ini juga untuk melakukan tindakan prevensi terhadap perilaku negatif yang mungkin muncul dalam diri siswa dan memberikan pencerahan terhadap perkembangan informasi psikososial di luar.

Faktor Pendorong dan Penghambat. Berdasarkan evaluasi pelaksanaan dan hasil kegiatan dapat diidentifikasi faktor pendukung dan penghambat dalam melaksanakan program pengabdian pada masyarakat ini. Secara garis besar faktor pendukung dan penghambat tersebut adalah sebagai berikut:

Faktor pendukung; a) Tersedia tenaga ahli yang memadai dalam pengembangan modul pelatihan konselor sebaya, b) Antusiasme siswa yang cukup tinggi untuk mengikuti kegiatan konselor sebaya, c) Dukungan kepala sekolah SMA Negeri 6 Bontoa yang menyambut baik pelaksanaan kegiatan pelatihan dan membantu tim pengabdi mengorganisasikan waktu dan tempat pelaksanaan kegiatan, d) Ketersediaan dana pendukung dari fakultas guna penyelenggaraan kegiatan pengabdian pada masyarakat ini.

Faktor penghambat; a) Siswa peserta pelatihan masih banyak yang belum memiliki pengetahuan awal tentang konselor sebaya, b) Keterbatasan waktu untuk pelaksanaan pelatihan sehingga beberapa materi tidak dapat disampaikan secara detil, c) Daya tangkap para peserta yang bervariasi, ada yang cepat namun juga ada yang lambat sehingga waktu yang digunakan kurang maksimal.

Hasil kegiatan pelatihan konselor sebaya secara garis besar mencakup beberapa komponen antara lain: a) Keberhasilan target jumlah peserta pelatihan, b) Ketercapaian tujuan pelatihan, c) Ketercapaian target materi yang 
telah direncanakan, d) Kemampuan peserta dalam penguasaan materi

Target peserta kegiatan telah direncanakan sebelumnya adalah 10 orang atau 2 orang perwakilan setiap kelas dari keseluruhan jumlah kelas yang ada di SMA Negeri 6 Bontoa. Dalam pelaksanaannya, kegiatan ini diikuti oleh 10 orang siswa yang menjadi perwakilan dari setiap kelas siswa di SMA Negeri 6 Bontoa. Hal ini menunjukkan bahwa kegiatan pelatihan konselor sebaya dikatakan berhasil/sukses.

Ketercapaian pendampingan konselor sebaya secara umum sudah baik, namun keterbatasan waktu yang disiapkan mengakibatkan tidak semua materi kegiatan pelatihan konselor sebaya dapat disampikan secara detil. Namun dilihat dari hasil latihan para peserta yang secara garis besarnya mereka sudah dapat melaksanakan konselor sebaya sesuai dengan tahapak dan teknik pelaksanaan konseling maka dapat disimpulkan tujuan pelaksanaan kegiatan pelatihan konselor sebaya dapat tercapai.

Ketercapaian terget materi pada kegiatan pelatihan konselor sebaya cukup baik, karena materi pelatihan konselor sebaya telah dapat disampaikan secara keseluruhan. Materi pelatihan yang telah disampaikan adalah: a) Konsep dasar konselor sebaya, b) Konsep dasar masalah dan jenis-jenisnya, c) Keterampilan dasar konseling, d) Bimbingan dan konseling kelompok

Kemampuan peserta dilihat dari penguasaan materi masih kurang dikarenakan waktu yang singkat dalam penyampaian materi dan kemampuan para peserta yang berbedabeda. Hal ini disebabkan jumlah materi yang banyak hanya disampaikan dalam waktu sehari sehingga tidak cukup waktu bagi para peserta untuk memahami dan mempraktekkan secara lengkap semua materi yang diberikan. Kendati demikian kegiatan ini masih dilanjutkan dengan kegiatan pendampingan oleh mahasiswa yang ikut dilibatkan dalam Tim pengabdian kepada masyarakat, sehingga peserta dapat melanjutkan proses latihan konselor sebaya.

Melalui proses pendampingan tersebut memberikan kontribusi positif bagi peserta kegiatan. Adapun kontribusi yang dimaksudkan antara lain: a) Kegiatan yang dilakukan telah mampu memberikan kontribusi positif terhadap remaja telah mampu membuka wawasan baru terhadap fungsi dan peran bimbingan konseling di sekolah. b) Sosialisasi keberadaan bimbingan dan konseling yang telah dilakukan pihak sekolah relatif kurang memadai sehingga siswa tidak mempunyai pemahaman yang benar tentang unit tersebut. c) Pelatihan telah mampu memberikan kesempatan individu memperbaiki karakter (positif) sesuai dengan kompetensi yang dibutuhkan oleh seorang konselor. Karakter tersebut antara lain : mau mendengarkan, empati, suka menolong (tidak egois), proaktif, kreatif dalam menyelesaikan masalah dan kesediaan untuk memikirkan masa depan dengan lebih jelas (Prakoso \& Wahyuni, 2015). Kompetensi yang dimiliki mampu mencegah timbulnya perilaku negatif lainnya yang dimiliki oleh sebagian remaja. d) Timbulnya kemampuan baru dalam aspek psikososial yang selama ini kurang berkembang yaitu memahami diri dan orang lain serta mau terlibat dalam masalah yang dihadapi orang lain. Di pihak sekolah mulai muncul gerakan mengembangkan kegiatan lain selain konseling, yaitu mengoptimalkan kegiatan bimbingan untuk menjembatani dan menghilangkan persepsi negatif terhadap bimbingan dan konseling dan terbentuknya komunitas konselor sebaya yang dapat menjadi agen perubahan bagi teman-temannya di sekolah.

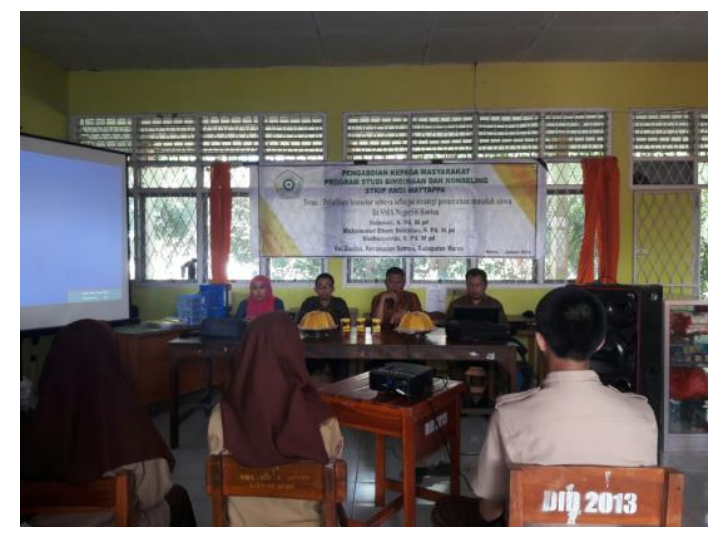

Gambar 1: Pembukaan Kegiatan

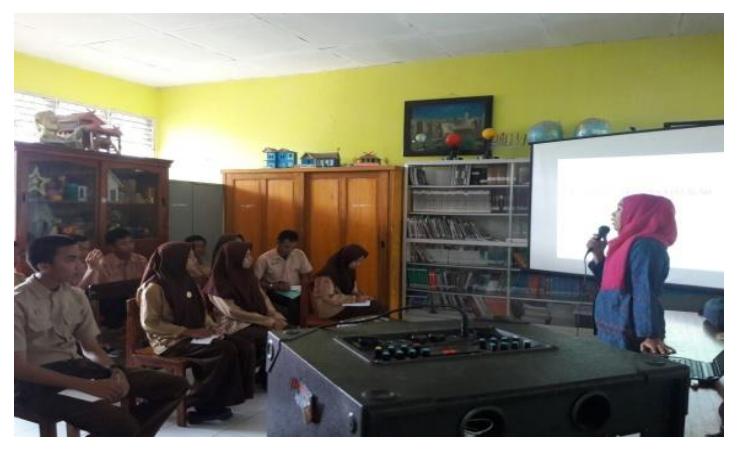

Gambar 2: Tim Memberikan materi kepada peserta 


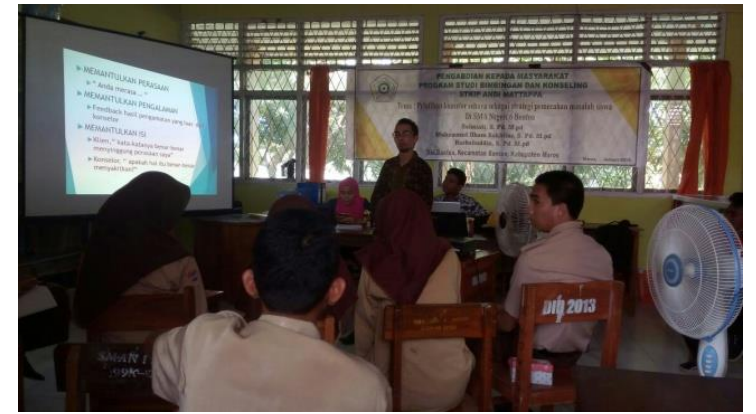

Gambar 3: Tim Memberikan materi kepada peserta

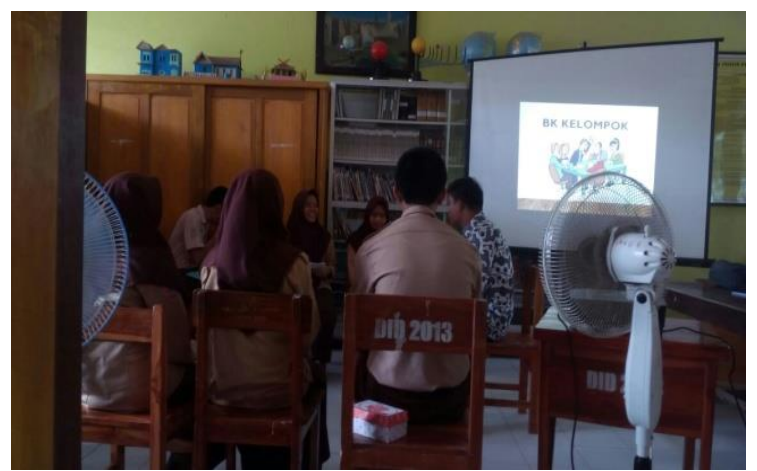

Gambar 3: Praktek Konseling Kelompok

\section{SIMPULAN DAN SARAN}

Berdasarkan implementasi kegiatan pengabdian masyarakat dan evaluasi dengan mitra dapat disimpulkan bahwa (a) Pelaksanaan kegiatan ini telah mampu meningkatkan performansi bimbingan konseling melalui kegiatan konseling sebaya, (b) Memberikan penghargaan dan perhatian terhadap siswa dengan melakukan kegiatan positif dalam bimbingan konseling di sekolah, (c) Dapat mengantisipasi munculnya perilaku negatif remaja (kenakalan remaja), (d) Mampu memberikan nilai tambah dalam bidang pengetahuan dan keterampilan untuk anak-anak sehingga dapat membantu tugas guru bimbingan dan konseling.
Berdasarkan evaluasi yang telah dilakukan dapat diajukan beberapa saran yakni: a) Waktu pelaksanaan kegiatan pengabdian perlu ditambah agar tujuan kegiatan dapat tercapai sepenuhnya, tetapi dengan konsekuensi penambahan biaya pelaksanaan. Oleh karena itu biaya pengabdian kepada masyarakat sebaiknya tidak sama antara beberapa tim pengusul proposal, mengingat khalayak sasaran yang berbeda pula. b) Adanya kegiatan lanjutan yang berupa pelatihan sejenis selalu diselenggarakan secara periodik sehingga dapat menciptakan suatu komuniatas konselor seabaya di sekolahsekolah sekaligus sebagai bagian penyelenggaran layanan bimbingan dan konseling di sekolah.

\section{DAFTAR RUJUKAN}

Aryani, F. (2013). Program Konselor Sebaya. Makassar: UNM

Agnis, D. S \& dkk. 2014. Pengaruh Kelompok Teman Sebaya (Peer Group) Terhadap Perilaku Bullying Siswa di Sekolah. Jurnal Sosietas Vol. 5 No. 1. h. 3

Hurlock, E.B. 2002. Psikologi Perkembangan, terj. Istiwidiyanti dan Soedjarwo. Jakarta: Erlangga.

Mardiana, Annisa Rizka. 2012. Studi Tentang Persepsi Siswa Pada Layanan Bimbingan Dan Konseling Dismk Se-Kecamatan Sukomanunggal Surabaya. Jurnal BK UNESA, Volume 3 Nomer 1,72-8072

Shohib, M, dkk. 2016. Pendampingan Kelompok Sebaya di Kota Batu. Jurnal Dedikasi. Volume 13, 34-38

Wahyudin. 2013. Hubungan Persepsi Siswa Terhadap Guru Bimbingan dan Konseling (BK) dengan Minat untuk Melakukan Konseling di Sekolah SMK Muhammadiyah 3 Yogyakarta, 